\title{
RACIONALIDADE E RACIONALIZAÇÃO EM MAX WEBER*
}

\section{Carlos Eduardo Sell}

Em passagem já célebre da "Observação preliminar" [Vorbemerkung], ${ }^{1}$ texto que abre e situa os escritos reunidos sob a rubrica dos Ensaios reunidos de sociologia da religiāo, Max Weber definiu da seguinte forma o problema de sua obra:

Racionalizações têm existido em diferentes esferas da vida, em uma grande diversidade de formas, em todas as culturas. Característico para sua diferença histórico-cultural é, em primeiro lugar: em quais esferas e em que direçôes elas foram racionalizadas. Portanto, trata-se novamente de identificar a peculiari-

* Este artigo sistematiza alguns dos principais resultados de pesquisa realizada entre 2008 a 2010 com auxílio do $\mathrm{CNPq}$ (Produtividade em Pesquisa), a quem agradeço o auxílio financeiro. dade específica e explicar a gênese do racionalismo ocidental e, no interior deste, do racionalismo moderno (GARS I, 1988, pp. 11-12; Weber, 2001, p. 21).

Consoante com a própria afirmação de Weber, o tema da racionalização é atualmente reconhecido por um grande segmento da literatura especializada como uma questão chave, quando não mesmo o tema essencial e primordial do conjunto da sociologia sistemática e histórico-comparativa deste autor. No entanto, se até aí podemos assinalar uma notável convergência (ainda que não consenso) da parte dos especialistas, o mesmo não ocorre quando se busca definir o tratamento weberiano dos conceitos de racionalidade [Rationalität] e racionalização [Rationalisierung]. Em relação a este aspecto as dificuldades são apontadas pelo próprio Weber que não se eximiu de advertir que: 
Pois bem, por esta palavra [racionalismo] pode se entender coisas bastante diversas, como as próximas exposições tornarão novamente compreensível. Há, por exemplo, "racionalizações" da contemplação mística, quer dizer, de um comportamento que, visto a partir de outros âmbitos da vida, é especificamente "irracional", bem como racionalizaçōes da economia, da técnica, do trabalho científico, da educação, da guerra, da justiça e da administração. Cada um desses âmbitos pode "racionalizar-se" sob pontos de vista e objetivos últimos da maior diversidade, e o que é "racional" para um pode, ao ser observado por outro, ser "irracional" (GARS I, 1988, p. 11; Weber, 2001, pp. 20-21).

Também é conhecida a afirmação de Weber, feita já em 1904 (na obra $A$ ética protestante e $o$ espirito do capitalismo), de que "o 'racionalismo' é um conceito histórico que encerra um mundo de contradiçōes" (2004, p. 69); e mesmo esta outra, encontrada seu ensaio de 1915 (a Einleitung [Introdução], conhecida pela sua tradução em inglês como Psicologia social das religiōes mundiais), com a seguinte advertência: "este é o lugar para lembrar mais uma vez que 'racionalismo' pode significar coisas bastante diferentes" (MWG I/19, p. 117; Weber, 2001, p. 259). Não bastassem as advertências do próprio Weber, o simples exercício do levantamento lexical revelaria que os termos em questão estão presentes em inúmeras passagens dos textos weberianos, elemento que dificulta ainda mais a tarefa de determinação de um conteúdo unívoco associado a estas noções.

No Brasil, a literatura que trata da teoria weberiana sob a perspectiva teórico-analítica vem se tornando cada vez mais sofisticada e, no bojo destas reflexões, o estudo dos conceitos de racionalidade e da racionalização recebe tratamento detalhado. Waizbort (1995), por exemplo, em texto introdutório que escreve para a tradução do escrito Os fundamentos racionais e sociológicos da música (Weber, 1995), destaca como a temática weberiana da racionalidade emerge no contexto de sua reflexão sobre a arte, acentuando ainda o quanto a ideia de processo de racionalização se articula no contexto da diferenciação das esferas de valor e ordens de vida.
No mesmo texto podemos encontrar ainda um prefácio de autoria de Cohn $(1995)^{2}$ que, de forma similar, aponta que o processo de racionalização, em Weber, se desdobra em dois níveis: a dimensão histórico-estrutural que remete à diferenciação das esferas de valor e a dimensão interna de cada esfera específica que remete à sua legalidade própria [Eingengesetzlichkeit]. E, não menos importante, as pesquisas de Pierucci $(1998,2003)$ iluminam o papel central que a categoria "desencantamento do mundo" (tanto na sua acepção religiosa como científica) possui no contexto da reflexão weberiana do processo de racionalização, na medida em que esta é uma variável fundamental e determinante para explicar as características que esse processo adquire na sua versão ocidental e moderna.

Visando prosseguir nesta mesma direção de trabalho, este artigo aborda alguns aspectos ligados à problemática weberiana da racionalidade e da racionalização. Tal tarefa, mais do que um hermético exercício hermenêutico, possui a vantagem intrínseca de nos situar em uma perspectiva privilegiada para o entendimento do sentido de sua obra, além de contribuir sobremaneira para a busca da compreensão do esquema analítico e metodológico que estrutura a ampla e sistemática sociologia weberiana dos processos de racionalização social e cultural. Por outro lado, trata-se de um exercício assaz complexo que, exatamente por pretender abarcar o pensamento weberiano em seu cerne e, principalmente, tomando-o no seu conjunto, comporta uma série de questôes correlatas. Enfrentar um tema de tamanha centralidade e complexidade nos obrigaria, entre muitas outras tarefas, a refletir a respeito 1) da própria concepção weberiana sobre o racional e o irracional, ${ }^{3}$ bem como sobre 2) os usos e sentidos do conceito de racionalidade em Weber, além de 3) determinar as relaçóes entre os conceitos de racionalidade e os tipos de ação e, por fim, 4) estabelecer o teor das conexōes entre os tipos ideais de "racionalidade" e os processos histórico-empíricos de "racionalização". Isto sem esquecer que todos esses temas não podem ser concebidos de forma isolada do restante do pensamento weberiano e envolvem ainda a relação com outros conceitos importantes, tais como desencantamento do mundo, intelectualização, burocratização, entre outros. 
Longe de enfrentar simultaneamente desafios tão abrangentes e diversos, este texto pretende abordar a questão a partir de uma ótica bastante pontual e específica: privilegiando como fio condutor da exposição os conceitos weberianos de racionalidade. Meu objetivo será submeter este último aspecto aos seguintes exercícios de análise. Do ponto de vista hermenêutico, procuro mostrar de que forma os comentadores têm procurado sistematizar os conceitos de racionalidade e racionalização em Max Weber (parte 1). Visando submeter esta mesma bibliografia a um exame crítico, desloco-me para o plano exegético, no qual realizo um inventário do uso e do significado dos conceitos weberianos de racionalidade material e formal e racionalidade teórica e prática nos próprios escritos de Max Weber (parte 2). Ao situar os conceitos weberianos de racionalidade em lugares e momentos diferentes do corpus de sua obra aponto para alguns limites da bibliografia secundária e destaco em que medida este elemento contribui para entender alguns dos aspectos relacionados com a teoria weberiana da racionalização (parte 3). A parte final retoma as conclusões do trabalho.

\section{As interpretaçóes de Weber: o estado da arte}

Neste tópico buscarei limitar minha análise da literatura secundária que trata do pensamento e da obra de Max Weber a um ângulo bastante específico e determinado. Trata-se de descrever o modo como os analistas têm se dedicado a elucidar o significado da noção de racionalidade (enquanto conceito) em Max Weber e como a partir destas definiçōes também se desdobram formas específicas de compreender a teoria weberiana da racionalização (enquanto análise empírica). Ainda que o problema da racionalização já fosse apontado, desde os anos de 1930, como a perspectiva analítica chave da obra weberiana, tentativas de determinação e sistematização lógico-analítica deste conceito são mais recentes e acompanham a vaga intensiva de estudos da obra de Weber que emerge a partir dos anos de 1970. Este tópico analisa o essencial da literatura especializada a respeito desse assunto, ${ }^{4} 1$ ) destacando as diferentes tipologias de racionalidade propostas pelos comentadores e, após, 2) descrevendo como a compreensão desta noção está intrinsecamente ligada à forma como estes mesmos intérpretes explicam a dinâmica que o processo de racionalização adquire no pensamento de Max Weber.

\section{O sentido da obra}

Para compreender a natureza e a importância deste especializado e, como logo veremos, deveras intrincado debate entre os comentadores de Weber a respeito da questão aqui proposta, uma rápida contextualização histórica do processo de recepção de sua obra constitui passo preliminar e necessário. No tocante à difusão das obras e da literatura secundária sobre Weber, dois países exercem, ainda hoje, um impacto decisivo: Alemanha e Estados Unidos.

$\mathrm{Na}$ Alemanha, a primeira voz a afirmar que a temática da racionalidade constitui o fio condutor de seu pensamento foi nada menos que sua principal biógrafa: Marianne Weber. Em tom enfático é a própria esposa de Weber que afirmará que "o reconhecimento da especificidade do racionalismo ocidental e do seu papel crescente na cultura ocidental [foi] uma de suas mais importantes descobertas" (1926, p. 349). Talvez seja esta a razão para que a primeira geração dos intérpretes de Weber (Lukács, [1923] 1974; Walther, 1926; Landshut, 1929; Freyer, 1930; Steding, 1932) enfatizasse a mesma ideia, levando um autor do porte de Karl Löwith, por exemplo, a dizer que "o fenômeno da racionalização constitui 'a grande linha mestra não só de sua sociologia da religião e de sua doutrina científica, mas, no fundo, de todo o seu sistema', e não por último, também de seus escritos políticos; ele representa para ele o caráter básico do modo de vida ocidental e em especial do nosso 'destino'” ([1929] 1997, p. 19).

No entanto, com os desatinos da Segunda Guerra Mundial, o centro de gravidade da discussão em torno do significado da obra de Weber atravessa o Atlântico e, em terras norte-americanas, especialmente por conta da influência de Talcott Parsons (1937), a temática da racionalização dá lugar ao conjunto de seus escritos teórico-metodológicos, passando a teoria weberiana da ação a ocupar o posto central como chave interpretativa de seu 
pensamento. Até mesmo a onda pós-parsoniana de leitura de Weber que se inicia nos Estados Unidos com os escritos de Hans Gerth e Charles Wright Mills (1946) e passa pela importante obra de Reinhard Bendix (1960), desembocando na maior ênfase em sua sociologia histórico-comparada, ainda que reafirme, retoricamente, a importância do tema da racionalização (Bendix e Roth, 1971), acaba, na prática, legando o tema a lugar secundário.

É somente com a Weber Renaissance, desencadeada na Alemanha, desde meados dos anos de 1970, acompanhando a republicação dos escritos do autor, que o tema da racionalização volta a ocupar o espaço de estatuto central da sociologia weberiana. Esta temática emergirá no contexto alemão e, passando pelos escritos de Seyfarth e Sprondel (1973), Benjamin Nelson (1974), Friedrich Tenbruck (1975, 1980), Wolfgang Schluchter (1981, 1989) e Jürgen Habermas (1987), espraiar-se-á também no contexto da produção em língua inglesa, como atestam ainda os textos Glassman e Murvar (1984), Lash e Whimster (1987), Bryan Turner (1992) e Stephen Turner (2000), entre outros. Desde então boa parte dos intérpretes e especialistas na obra de Weber retomou a tese de que, em se tratando deste autor, racionalização é, de fato, o fio condutor que tece as tramas de seus múltiplos escritos e confere unidade à diversidade de temas teóricos, históricos e empíricos enfrentados pela sua reflexão.

No entanto, a questão está longe de ser consensual, e tanto na Alemanha como nos Estados Unidos não faltam vozes discordantes a sustentar que a leitura de Weber sob o foco da racionalização não constitui mais do que um desvio na compreensão do escopo de seu pensamento. ${ }^{5}$ Enquanto para Hennis (1996) - outro intérprete alemão contemporâneo - o que temos em Weber seria, na verdade, uma antropologia filosófica (a reflexão sobre a Humanidade/Menchestum), para um norte-americano como Kalberg (1994), racionalização constitui tão somente um entre tantos outros recursos heurísticos que permeiam a sociologia de Weber, mas não o centro de sua obra. Há ainda visões bem mais heterodoxas, como a de Swedberg (2005), para quem, ao fim e ao cabo, a obra de Weber jamais teria deixado o campo da economia (ainda que sob uma ótica de tipo sociológico).
Não surpreende, portanto, que, diante do alcance da disputa em torno do papel determinante que o tema da racionalização assumiu entre os comentadores de Weber, a busca pela determinação do lugar e da função das noções de racionalidade e da própria racionalização no esquema analítico deste autor tenha se tornado um assunto vital. Para enfrentar o que se supõe ser o elemento estruturante da ampla e sistemática sociologia weberiana, uma vasta e complexa literatura especializada vem se desenvolvendo nas últimas décadas, trabalhos que procuro sumarizar nos dois tópicos que seguem.

\section{O problema da racionalidade}

Não é intento da sociologia weberiana a elaboração de uma teoria da racionalidade (perspectiva filosófica) em si mesma, pois esta é apenas condição ou meio para uma tarefa que a engloba e lhe confere sentido: a explicitação do processo histórico e sociocultural de racionalização ocidental e moderno (perspectiva sociológica). Ao mesmo tempo, em Weber, o processo de racionalização não é uma noção que pode ser definida de maneira prévia, como um tipo ideal que precede a análise, pois se trata de um tópico que o pensador desenvolve sempre de forma situada, com um sentido que emerge sempre em ato, quer dizer, embutido no próprio processo de análise. Já em relação à noção de racionalidade, uma análise lexical e epistemológica é possível e, como veremos, não faltam tentativas de sistematizar o sentido dos conceitos de racionalidade nos escritos de Weber.

A tarefa, por certo, é difícil, o que levou até mesmo alguns comentadores a evitar a terminologia empregada pelo próprio Weber na suposição de que a adoção de categorias alternativas favoreceria nosso entendimento. Modelo deste tipo de procedimento é o texto de Ann Swidler (1973) que, evitando o que supõe ser uma insuperável confusão terminológica do próprio Weber, propõe-se a reformular sua visão em torno de três categorias distintas: racionalismo, racionalidade e racionalização. Em sua visão reformulada, o racionalismo é uma atitude pragmática, orientada para a consecução imediata de objetivos e fins utilitários; a racionalidade refere-se a objetivos ordenados em 
relação a um sistema consciente de significados e valores, qual seja, um processo de sistematização das ideias operado pelos especialistas do campo religioso; por fim, a racionalidade tem a ver com sua institucionalização social: a ação racional referente a fins seria produzida apenas pelo controle das ações mediante as ideias. A proposta, como fica evidente, em nada contribui para superar a suposta equivocidade weberiana e redunda, ao final, em uma sistematização não apenas confusa, mas acima de tudo duvidosa, posto que muito longe do que os originais de Weber indicam.

Mais promissora, a via exegética se impôs, mas nem por isso dirimiu todas as dúvidas. Um exame global da produção existente apontará que a literatura foi se encaminhando para uma razoável concordância quanto se trata da tarefa preliminar de identificar em Weber quatro tipos de racionalidade, mas sensíveis diferenças aparecem quando se trata de descrever o significado ou conteúdo de cada um dos termos envolvidos. Para um determinado grupo de intérpretes, a dicotomia racionalidade material e formal recebe um tratamento privilegiado, sendo o segundo elemento a chave interpretativa do conceito weberiano de racionalidade. Visão contestada por aqueles que tendem a explicar a perspectiva weberiana de racionalidade a partir das suas variantes teóricas e práticas, com particular privilégio para as últimas. E, terceira solução possível, também há quem busque diferenciar e descrever cada um dos quatro tipos ideais de racionalidade propostos por Weber em sua singularidade e especificidade, renunciando a tentativa de reduzi-los a um denominador comum. Vejamos cada uma dessas propostas de interpretação separadamente.

O artigo de Arnold Eisen (1978) é um exemplo bastante ilustrativo da primeira tendência. Para tal intérprete, o conceito de racionalidade de Weber é, de fato, múltiplo, mas de forma nenhuma opaco ou fluido; ao contrário, sua visão da racionalidade seria perfeitamente coerente e consistente. Para Eisen, existem seis diferentes dimensōes associadas permanentemente ao conceito de racionalização: propósito (busca consciente de realização de objetivos), calculabilidade (capacidade de adequação de meios e fins), controle (quando a ação é desenvolvida de forma autônoma e não heterônoma), coe- rência lógica (quando não apresenta contradições), universalidade (quando abstração, generalidade e impessoalidade se opõem ao particularismo) e sistematicidade (quando as partes da organização estão integradas visando à consecução dos fins almejados). Cada uma delas possui a mesma base conceitual e remete-nos, como sustentáculo, ao conceito de racionalidade formal. Por sinal, o próprio Eisen sustenta que o tipo ideal "racionalidade substantiva" (assim o autor se refere à racionalidade material) exerce apenas função subordinada, apontando para critérios que limitam a racionalidade formal: sua função consiste apenas em revelar que por trás da racionalidade formal da conduta de vida puritana vicejavam elementos de ordem ética e substantiva.

A mesma tendência de apreender o conteúdo do conceito weberiano de racionalidade com base em sua variante formal pode ser identificada no livro de Roger Brubaker (1984). Também ele reconhece a existência de múltiplas conotaçôes na ideia weberiana de racionalidade, o que não significa qualquer impedimento para que se reconheça no interior desta diversidade um substrato comum. Em Weber, o sentido de racionalidade pode estar associado a nada mais do que dezesseis conotações inter-relacionadas: deliberado, sistemático, calculável, impessoal, instrumental, exato, quantitativo, regido por regras, previsível, metódico, proposital, sóbrio, meticuloso, eficaz, inteligível e consistente. A conclusão de Brubaker é a mesma de Eisen, qual seja, o tipo formal é que responde pelo conteúdo do conceito weberiano de racionalidade. Em ambos os autores, a busca por um fundamento conceitual para a teoria weberiana da racionalidade contribui para o aprofundamento do entendimento de sua dimensão formal, mérito que, todavia, relega sua dimensão teórica/prática ao esquecimento.

Em direção oposta, também não faltam autores que concentram sua atenção no par racionalidade teórica/prática e concebem este segundo tipo como a chave interpretativa da visão weberiana de racionalidade. Esta é, enfaticamente, a posição de Habermas (1987), para quem a visão weberiana de racionalidade se reduz, em última instância, apenas à racionalidade prática. Para sustentar sua posição, passo primeiro, Habermas reduz o alcance da racionalidade teórica: tratar-se-ia apenas de uma 
teoria da cultura que descreve o processo de sistematização das imagens do mundo e a lógica interna das esferas de valor. Assim, seria apenas no nível da racionalidade prática que Weber estabeleceria uma conexão entre ela e sua teoria da ação, ou seja, apenas no plano "prático" é que o conceito weberiano possuiria significado sociológico. Daí que, passo segundo, o que importa a Habermas é esclarecer o conteúdo da racionalidade prática. Para o autor, como pressuposto da visão weberiana da racionalidade encontra-se um conceito amplo de técnica, enquanto emprego regulado de meios. A partir desta premissa geral, Habermas diferencia o conceito de racionalidade prática em um tríplice aspecto: 1) a racionalidade instrumental refere-se à utilização de meios, e seu critério de eficácia é o emprego de meios para fins dados; 2) a racionalidade eletiva refere-se à eleição de fins e pode ser medida tanto pela correção do cálculo destes fins em função de valores articulados com precisão, como pela escolha de meios e a concomitante avaliação das condiçôes de contorno; 3) a racionalidade normativa refere-se à orientação por valores e é medida pela força sistematizadora e unificante desses valores, bem como pela capacidade de penetração desses princípios como guia das ações sociais. A partir daí, passo terceiro, Habermas apresenta uma nova visão do conjunto, assim disposto. A racionalidade prática possui uma dupla dimensão: por um lado, a racionalidade formal (junção entre o aspecto instrumental e eletivo da racionalidade prática); por outro, a racionalidade material (ou seja, a racionalidade normativa). O esquema habermasiano é, de fato, complexo, mas em síntese ele consiste em subordinar a dimensão material e a dimensão formal da racionalidade à sua dimensão prática, que passam a ser concebidas como elementos diferentes desta forma de racionalidade. Habermas não descarta a terminologia weberiana (todos os tipos ideais de Weber são apresentados), mas ignora o valor da racionalidade teórica e subordina os demais tipos (formal e material) a um conceito que a todos integra: a racionalidade prática.

Nem todos os intérpretes tendem a privilegiar apenas um dos pares tipológicos de racionalidade propostos por Weber, acentuando ora sua dimensão "formal", ora sua dimensão "prática" como a base do conjunto. Porém, as soluções para determinar o conteúdo e o significado de cada um dos tipos de racionalidade também possuem diferenças entre si.

Donald Levine (1981), por exemplo, inicia sua exposição distinguindo dois níveis distintos nos quais Weber insere o problema da racionalidade: subjetivo e objetivo. O primeiro trata dos tipos de ação. Neste caso, a racionalidade como qualidade mental da ação estaria presente na distinção weberiana entre compreensão racional e compreensão empática e na sua diferenciação entre formas racionais e não racionais de ação social. A racionalidade objetiva, por sua vez, configura-se no nível na história e seria pensada por Weber nas diferentes ordens sociais de vida e em seus desenvolvimentos históricos específicos. É somente neste segundo nível que Levine distingue quatro diferentes tipos de racionalidade, que ele assim denomina: racionalidade instrumental (busca metódica de um fim dado mediante o cálculo preciso dos meios empregados e de suas consequências); racionalidade conceitual (domínio da realidade pela via da abstração e da generalização); racionalidade substantiva (ou também material, que se move no plano ético e se refere a padrões normativos de avaliação da conduta); racionalidade formal (concebida como maximização da previsibilidade da conduta em esferas sociais específicas).

Uma proposta muito similar à anterior também pode ser encontrada em Stephen Kalberg (1980). Em sua sistematização, a racionalidade prática é entendida como todo caminho de vida que vê e julga a atividade mundana em relação a interesses puramente pessoais e pragmáticos. Nesta versão, a realidade é aceita como tal e o indivíduo apenas calcula os meios mais adequados para lidar com as dificuldades presentes. A racionalidade teórica remete a processos cognitivos e envolve a dominação consciente da realidade mediante a construção e o incremento de conceitos cada vez mais precisos e abstratos. Este tipo decorre da necessidade humana de conferir um significado último à sua ação no mundo. $\mathrm{O}$ terceiro tipo é a racionalidade substantiva que ordena os padrões de ação a partir de postulados de valor. Ela envolve a adoção de critérios éticos com o qual a realidade deve ser julgada e, dessa forma, tende a conformar e orientar a ação. A racionalidade formal subordina a conduta 
autointeressada em referência à aplicação universal de regras, leis ou regulações. A ação formal tende a superar o particularismo e o personalismo na direção da universalidade das condutas. Esta forma de racionalidade é típica da era moderna e se concretiza especialmente nos campos da burocracia, da economia, do direito, da ciência e mesmo da religião.

Ainda no interior do terceiro conjunto aqui descrito, a sistematização teórica proposta por Wolfgang Schluchter merece atenção particular, não apenas porque se trata de um dos mais notáveis especialistas na obra de Max Weber, mas também pela oscilação de suas interpretaçōes, fator que por si mesmo já demonstra a complexidade da questão aqui envolvida.

Em seus primeiros trabalhos, Schluchter (1981) apresentou uma tipologia do racionalismo e dos estágios de racionalização segundo três critérios. Em primeiro lugar, o racionalismo refere-se à capacidade de controle mediante o cálculo: o racionalismo científico-tecnológico seria uma consequência do conhecimento empírico e prático. $\mathrm{O}$ segundo tipo é o racionalismo ético-metafísico, que diz respeito à sistematização de modelos de significado e envolve a elaboração intelectual e a sublimação deliberada dos fins últimos. Como tal, ele é consequência não apenas da compulsão humana para compreender o mundo não só a partir de um sentido ordenador, mas também como um desiderato humano de tomar uma posição unificada e consistente diante da realidade. $\mathrm{O}$ racionalismo prático, por sua vez, refere-se à realização do modo metódico de vida e é resultado da institucionalização das configuraçōes de significados e interesses.

Em suas obras posteriores, no entanto, este estudioso modifica seu entendimento da questão. Para ele, a pesquisa de Weber não tem como foco a construção de uma teoria global da racionalidade, pois isto implicaria na adoção de uma filosofia da história. Por esta razão, a extensa pesquisa de Schluchter (1989) limita-se a identificar os diferentes tipos histórico-culturais de racionalismo que teriam sido elaborados por Weber para entender a civilização chinesa, indiana e ocidental (judaísmo e protestantismo) e, principalmente, a explicitação do esquema de fundo no qual opera a pesquisa comparativa de Weber, chamada por Schluchter de perspectiva "desenvolvimental". ${ }^{6}$
Todavia, observando seus textos mais recentes, vemos que a exegese de Schluchter $(1999,2009)$ sofre nova guinada, retomando a tipologia weberiana do racionalismo. Pensada novamente em três planos distintos, nesta nova versão o conceito de racional em Weber organiza-se da seguinte forma: no plano da orientação da ação, ele se rege pela ação racional com relação a valores e pela ação racional com relação a fins; no plano societário da coordenação da ação (em que operam as instituições sociais), o racional desdobra-se nos conceitos de racionalidade formal e material; no plano cultural da coordenação de sentido, ele estaria guiado pelos conceitos de racionalidade teórica e prática. Nesta nova versão, portanto, a base da concepção weberiana da racionalidade seria sua teoria da ação, operando os conceitos de racionalidade material e formal no contexto societário e os conceitos de racionalidade teórica e prática no contexto cultural.

Como se depreende da exposição aqui realiza$\mathrm{da}$, as sistematizaçōes propostas pelos comentadores a respeito da visão weberiana sobre a racionalidade são heterogêneas e divergem em aspectos cruciais, quanto a sua terminologia, conteúdo e, principalmente, significado. $\mathrm{O}$ recurso aos próprios textos de Weber parece ser, pois, um recurso incontornável para tentar dirimir essas diferenças e chegar a uma compreensão o mais próxima possível das intençôes deste pensador. Mas, antes de recorrer aos próprios escritos weberianos, destacarei ainda como a sistematização dos conceitos de racionalidade reflete e condiciona também as propostas de sistematização da noção weberiana de racionalização (enquanto processo).

\section{O problema da racionalização}

Em seu nível empírico, ou seja, compreendida em seu âmbito cultural e social, a teoria weberiana da racionalização não pode ser considerada derivação necessária de uma teoria da racionalidade que a precede. Para elidir tal desvio idealista basta apenas lembrar que, em sua base, a racionalização que Weber pretende analisar tem como sustentáculo indispensável sua teoria da ação, este sim o fundamento inequívoco de todo seu edifício sociológico. Os conceitos weberianos de racionalidade 
atuam apenas no plano metodológico e operam, antes, como recurso heurístico e meio de análise. Trata-se de um dos vários recursos conceituais que Weber utilizou para elaborar sua teoria e, ainda que não sejam exclusivos, eles representam um fio condutor privilegiado e determinante para nos ajudar a entender o modus operandi, ou seja, o modo como Weber efetivamente entendia a dinâmica da racionalização no curso da ação, da história e da vida social. Dessa forma, boa parte do que os intérpretes de Weber explicam sobre a racionalização está ligada ao modo como estes mesmos intérpretes compreendem o papel dos conceitos weberianos de racionalidade no bojo desse processo. Trata-se de um ponto de vista que nos permite facilmente ordenar a literatura a respeito.

Para um primeiro grupo, o processo de racionalização é lido como a gênese e a institucionalização de formas de conduta orientadas pela racionalidade formal. É exatamente esta versão que vamos encontrar no texto de Roger Brubaker (1984). O intérprete realiza um minucioso trabalho de descrição dos processos internos analisados por Weber em esferas distintas da vida social, como a economia, o direito, a política (burocracia) e a religião. Todavia, mais do que a especificidade que Weber confere a cada um desses campos, o que Brubaker procura captar são as similitudes estruturais, ou seja, os elementos comuns que, segundo Weber, subjazem a todo processo. Na leitura aqui proposta, a legalidade própria das diversas ordens de vida e esfera de valor não é negada, mas seu acento recai sobre os traços que, operando em cada uma delas, lhes conferem sentido e direção homogêneos. Dentre esses elementos comuns, Brubaker identifica traços como a despersonalização das relaçôes sociais, o refinamento das técnicas de cálculo, a importância contínua do conhecimento especializado e a crescente extensão das técnicas de controle racional sobre os processos naturais e sociais. É exatamente esta série de características que nos permite afirmar que a multiplicidade e a especificidade das esferas sociais modernas se vêm arrastadas por uma dinâmica similar, diagnóstico que Weber formula em termos da transição de uma racionalidade material para uma racionalidade formal.
Se no trabalho de Brubaker toda a dinâmica do processo de racionalização na perspectiva weberiana se resolve à luz do conceito de racionalidade formal, Kalberg (1980) possui o mérito de reservar um papel importante não apenas para ela, mas também para sua contraparte, a racionalidade material (substantiva). $\mathrm{Na}$ visão deste intérprete é a racionalidade substantiva que possui a prioridade analítica no esquema de Weber, embora seja a racionalidade formal que detenha este posto quando a questão é posta em termos empíricos. Vejamos de que modo Kalberg formula sua proposta de leitura da dinâmica da racionalização em Weber.

No plano analítico, já vimos anteriormente que Kalberg é um dos intérpretes que se insere no grupo dos que apontam quatro diferentes tipos ideais nos escritos de Weber. Mas, quanto se trata de apontar de que modo esses quatro conceitos operam como recursos analíticos no esquema weberiano, ele atribui bem menos valor ao primeiro dos pares em questão. Isso decorre do fato de que em sua leitura cada um dos quatro tipos de racionalidade possui potencial diferenciado de padronização da ação e de conformação de um modo metódico de vida. Com base nesses dois critérios estaríamos em posse de instrumentos que nos permitem avaliar qual a relação entre os quatro conceitos de racionalidade e as formas concretas pelas quais Weber articula teoricamente sua análise do processo de racionalização social. A partir dessas balizas, o exame dos primeiros pares desemboca no seguinte veredicto: a racionalidade teórica não possui maior relevância analítica, pois seus efeitos não incidem no plano sociológico da ação (ela é significativa apenas quando se trata de sua influência entre os segmentos sociais formados por intelectuais). Este não é o caso da racionalidade práti$c a$, que, a despeito de seu papel histórico, carece de um caráter metódico e sistemático, deixando a ação refém de interesses momentâneos (efêmeros) e mutáveis (variáveis). Para Kalberg, bem mais relevante é o papel da segunda tipologia, pois a racionalidade material e a racionalidade formal são as únicas formas que possuem algum potencial para padronizar as ações sociais. Porém, há uma sensível diferença entre elas, dado que somente a racionalidade material (Kalberg prefere o termo 
substantiva) pode engendrar um modo metódico de vida. Concretamente, a racionalidade formal até é capaz de subordinar a racionalidade prática em esferas específicas da vida social (burocracia, por exemplo), mas falha em transferir a mesma lógica para o conjunto da vida do indivíduo e as demais esferas da vida social. Este não é o caso da racionalidade substantiva, que oferece prêmios psicológicos para a ação ética no mundo. Ela não envolve apenas normas formais, na medida em que consegue superar o hiato entre o prescrito e a conduta de fato. Trata-se, conforme a visão weberiana, de uma "ética prática". Em outros termos, a racionalidade substantiva torna-se efetiva (ampla e contínua) quando, através de um processo de racionalização substantiva dos valores, deriva para uma ética racional de ação no mundo, quer dizer, quando traduzida em racionalidade ética.

Apesar de acentuar a prioridade analítica do conceito de racionalidade substantiva no esquema conceitual weberiano, no plano empírico, Kalberg (1990) julga que a prioridade incide mesmo sobre o conceito de racionalidade formal. Ele acredita que a teoria weberiana da modernidade tem como escopo mostrar que a racionalidade ético-substantiva do mundo religioso é substituída pela racionalidade formal das esferas da ciência, da economia, do direito, da burocracia etc. Em outros termos, a modernização pode ser entendida como uma suplantação da racionalidade substantiva pela racionalidade formal.

Apesar das sensíveis diferenças entre as propostas de interpretação de Weber que localizamos em Brubaker e Kalberg, ambos adotam como premissa a tese de que são os conceitos de racionalidade material e formal que articulam e estruturam analiticamente a teoria weberiana do processo de racionalização social. Esses autores secundarizam a sociologia histórico-comparada das religióes universais de Weber, e a dualidade racionalidade teórica/racionalidade prática, quando não está ausente, ocupa um lugar marginal. Porém, tudo se passa de forma completamente diferente quando se trata de autores cuja compreensão da visão weberiana do processo de racionalização é orientada prioritariamente em função da dualidade "racionalidade teórica e prática”.
$\mathrm{Na}$ ampla sistematização de Habermas (1987), a teoria weberiana da racionalização desdobra-se em duas dimensões. De um lado temos a racionalização cultural como desencantamento das imagens do mundo e, de outro, a racionalização social como materialização da racionalidade prática no agir social. Tal entendimento é possível porque, como já demonstramos, Habermas cinde a racionalidade teórica e a racionalidade prática, situando a primeira na teoria weberiana da cultura e a segunda na teoria weberiana da ação social. Habermas entende que a sociologia weberiana das religiōes universais tem como meta analisar a maneira pela qual as imagens religiosas de mundo possuem potenciais distintos de racionalização. Tais imagens podem ser diferenciadas segundo suas representaçôes do divino (cosmocêntrica/teocêntrica), do mundo (positiva/negativa), vias de salvação (mística/ascética) e valoração do mundo (teórica/prática). Segundo Habermas, Weber teria mostrado que as religiōes da China (confucionismo e taoismo) e da Índia (hinduísmo e budismo) distinguem-se da experiência ocidental porque, ao contrário do protestantismo ascético, não apresentam potenciais positivos de racionalização cultural. Esta, efetivamente, ocorreu apenas no Ocidente.

Em seguida, Habermas passa a descrever como este processo pode ser entendido do ponto de vista sociológico, ou seja, como processo de racionalização social. Neste caso o protestantismo ocupa papel-chave, pois é o portador histórico da racionalidade prática predominante na modernidade. O racionalismo prático, potencialmente estimulado pela imagem religiosa vigente no Ocidente, institucionalizou-se na vida social moderna mediante a conduta ético-metódica do protestantismo ascético, abrindo caminho para o surgimento de complexos institucionais, como a economia capitalista e o Estado burocrático (esferas sociais com formas de vida objetivadas e desprovidas de conteúdo ético). Contudo, ao analisar o conflito entre a dinâmica valorativa das religiōes e a legalidade própria das ordens sociais modernas, Habermas não a apresenta em termos do conflito entre racionalidade material e formal. Mesmo a análise habermasiana da sociologia do direito de Weber, que indica (na terminologia de Habermas) a falta 
de ancoragem dos sistemas funcionais no mundo da vida, não faz nenhuma referência à dicotomia material/formal. Em sua formulação, todo o conjunto da teoria weberiana da racionalização é explicado em termos da dicotomia teórico/prático, com especial ênfase para o papel preponderante do segundo elemento.

A reconstrução analítica do esquema conceitual weberiano, efetuada por Schluchter (1981, 1989, 2009), também tem como sua marca fundamental o fato de ser desdobrada a partir do conjunto de sua sociologia da religião. Este autor distingue em Weber dois conjuntos no âmbito das religiôes universais: as religiōes culturais e as religiôs de salvação. Esses diferentes sistemas religiosos podem ser diferenciados ainda segundo dois fatores: suas camadas sociais portadoras (que tendem para o racionalismo teórico ou o racionalismo prático) e suas diferentes imagens religiosas (que determinam a relação do homem com o mundo). Da complexa combinação desses fatores, Schluchter desenha um amplo quadro sintético dos estudos histórico-comparativos de Weber. Em cada uma das principais civilizações mundiais, ele teria identificado formas culturais específicas de racionalismo. As religiōes da China representam uma forma de racionalismo de acomodação ao mundo; as da Índia como religiōes de salvação de caráter místico e extramundano, conduzem ao racionalismo da fuga do mundo. Já o protestantismo, como religião de salvação de caráter ascético e intramundano, engendra o racionalismo da dominação do mundo. A versão ascético-protestante representa um momento diferenciado da evolução do cristianismo, diferindo-o tanto do monasticismo católico (religião de salvação ascética e extramundana que leva à superação do mundo), como de sua raiz judaica que, por sinal, possui um caráter muito específico, qual seja, trata-se de uma religião de salvação (que não é universal) com um sentido intramundano, cuja forma de racionalismo é caracterizada como aceitação do mundo.

Observadas em conjunto, a leitura hermenêutica que segue das pesquisas de Habermas e de Schluchter aponta para outra forma de compreensão do processo de racionalização. Tomando como ponto de partida a tese de que a chave de leitura da teoria weberiana da racionalização se encontra em sua sociologia da religião, ambos os autores confluem para a análise do papel essencial do protestantismo ascético como fator que está na origem do racionalismo prático (Habermas) ou mesmo do racionalismo da dominação do mundo (Schluchter) que permeiam a modernidade.

Da mesma maneira que em relação ao conceito de racionalidade, também a literatura que busca explicitar o cerne da teoria weberiana da racionalização se encontra em franco desacordo, e as propostas, além de se utilizarem dos conceitos de racionalidade das formas mais variadas, também divergem sobre o modo como Weber articulou, analiticamente, sua exposição dos processos de racionalização histórica e socioculturais. Neste ponto, a literatura secundária tende para um acentuado dualismo, e enquanto uma determinada vertente deriva sua teoria da racionalização a partir do foco exclusivo em sua sociologia da religião, outra vai buscar o núcleo da teoria na tese da progressiva preponderância do tipo formal de racionalidade nas diversas esferas sociais modernas.

\section{A racionalidade nos escritos de Weber}

A revisão sistemática do debate sobre o conceito weberiano de racionalidade e sobre sua teoria da racionalização no seio da bibliografia especializada mostra o refinamento e a complexidade que possui, atualmente, a hermenêutica da obra de Weber. Por outro lado, o estado da questão é de franco desacordo, quando não de uma polifonia confusa e hermética de tipologias e propostas de elucidação. Diante de tamanha divergência, procuro mostrar que o exercício de situar o uso que Weber faz de seus conceitos de racionalidade em locais e momentos diferentes de seus textos e escritos nos oferece algumas pistas importantes para prosseguir na tarefa de compreensão do modo como se estrutura e articula o esquema construído por Weber em torno dos processos de racionalização. Meu propósito será demonstrar que, pela via exegética, podemos confirmar que duas díades estruturam a compreensão weberiana da racionalidade: os tipos ideais de racionalidade material/formal e teórica/prática. 
Racionalidade material e formal

Não encontramos propriamente definições prévias do que seja a racionalidade material e formal nos escritos weberianos. Embora sua ocorrência possa ser rastreada também nos textos de sociologia da religião de Weber, é em outro âmbito textual que sua utilização adquire função vital: o conjunto inacabado de textos que, postumamente, Marianne Weber intitulou Economia e sociedade. $\mathrm{O}$ que podemos verificar analisando este escrito é que os conceitos aqui em questão já aparecem como instrumentos de análise em contextos determinados (especialmente no tocante às esferas econômica e jurídica). Deles não encontramos tipificações preliminares e é somente a partir de sua utilização nestes dois âmbitos que podemos determinar seu conteúdo. Também é bastante notório que a noção de racionalidade ocupa um lugar central na discussão weberiana dos tipos de ação social e desempenha papel-chave no exame dos tipos de dominação. Como pretendo ater-me apenas ao uso explícito que Weber faz dos conceitos de racionalidade formal e material, dispensarei sua análise do Estado moderno burocrático. Porém, como a teoria da ação possui um vínculo direto com a análise weberiana dos processos de racionalização, referências ao tema, mesmo que breves, são imprescindíveis.

A diferenciação entre ação racional com relação a fins, ação racional com relação a valores, ação afetiva e ação tradicional envolve a consideração dos diferentes graus de racionalidade presentes na própria ação. $\mathrm{O}$ primeiro tipo funciona como ideal, e os restantes representam um desvio em relação ao primeiro. Seguindo-se a explicação de Schluchter (1996), Weber constrói essa escala tendo em mente a articulação entre quatro elementos: os meios, os fins, os valores e as consequências da ação. A ação será tão mais racional quanto mais o ator levar em consideração todos tais aspectos. Esta discussão é fundamental, pois a problemática da racionalidade, em Weber, é elaborada tendo-se em vista compreender, a partir dela, a especificidade das açóes sociais. Resta, contudo, um problema: qual a relação que Weber estabelece entre os tipos de ação, por um lado, e os tipos de racionalidade, por outro? No decorrer deste texto pretendo retomar este ponto, mas, por ora, chamo a atenção para o assunto central deste tópico: a compreensão da tipologia weberiana da racionalidade formal e material.

É apenas no segundo capítulo, aquele que trata da esfera econômica, que o texto de Economia e sociedade apresenta, pela primeira vez, a distinção entre duas formas de racionalidade:

[...] chamamos racionalidade formal [formale Rationalität] de uma gestão econômica o grau de cálculo tecnicamente possível e que ela realmente aplica. Ao contrário, chamamos racionalidade material [materiale Rationalität] o grau em que o abastecimento de bens de determinados grupos de pessoas (como quer se definam), mediante uma ação social economicamente orientada, ocorra conforme determinados postulados valorativos (qualquer que seja sua natureza) que constituem o ponto de referência pelo qual este estabelecimento é, foi ou poderia ser julgado. Esses postulados têm significados extremamente variados (Weber, 1994, p. 52, grifos no original).

Conforme Weber, enquanto o conceito de racionalidade formal possui um conteúdo inequívoco, a racionalidade material é inteiramente vaga. Para ele "uma gestão econômica é formalmente 'racional' na medida em que a 'previdência' essencial em toda economia racional pode exprimir-se e de fato se exprime em consideraçôes de caráter numérico e calculável” (Idem, p. 52). Já o que caracteriza a racionalidade material é que ela "estabelece exigências éticas, políticas, utilitaristas, hedonistas, estamentais, igualitárias ou outras quaisquer, e as toma como padrão dos resultados da gestão econômica" (Idem, p. 52). Entre os exemplos arrolados por Weber estão o comunismo e o socialismo, bem como os grupos éticos e igualitários. Weber considerava o dinheiro como “o meio de cálculo econômico 'mais perfeito', isto é, o meio formalmente mais racional de orientação da ação econômica" (Idem, p. 53). Em relação ao dinheiro, ele esclarece quais são as condições materiais específicas que sustentam este processo: "o cálculo em dinheiro alcança o grau máximo de 
racionalidade como meio de orientação de caráter calculável [...] com a condição material do máximo de liberdade de mercado" (Idem, p. 68).

A distinção entre as formas material e formal de racionalidade também será retomada por Weber no capítulo dedicado à esfera do direito. $\mathrm{Na}$ busca pela determinação das suas qualidades importam ao pensador "o grau e a natureza da racionalidade do direito, sobretudo, como é claro, do direito economicamente relevante (o atual 'direito privado')" (Weber, 1999, p. 11, grifo no original).

Do ponto de vista teórico-analítico, "um direito pode ser 'racional' em sentido muito diverso, dependendo do rumo que toma a racionalização no desenvolvimento do pensamento jurídico" (Idem, p. 11). Visando determinar, pois, seu conteúdo, Weber apresenta dois critérios para analisar a racionalidade do direito. O primeiro, a generalização, significa "a redução das razões que determinam a decisão, no caso concreto, a um ou vários 'princípios', que são as 'disposições jurídicas”' (Idem, p. 11). O segundo elemento é a sistematização do direito: "ela significa o inter-relacionamento de todas as disposiçōes jurídicas obtidas mediante a análise, de tal modo que formem entre si um sistema de regras logicamente claro, internamente consistente e, sobretudo, em princípio, sem lacunas" (Idem, p. 12).

A partir destes critérios de formalidade e materialidade (combinados com a racionalidade e a irracionalidade), Weber desenha sua conhecida tipologia das formas do direito: o direito formal irracional ou racional e o direito material racional ou irracional. Para ao autor são (1) formalmente irracionais as formas jurídicas nas quais "são empregados meios que não podem ser racionalmente controlados por exemplo, a consulta a oráculos ou a sucedâneos destes" (Idem, p. 12). Em um segundo tipo (2) as formas jurídicas podem ser materialmente irracionais, "na medida em que a decisão é determinada por avaliaçôes totalmente concretas de cada caso, sejam estas de natureza ético-emocional ou políticas, em vez de depender de normais gerais" (Idem, p. 13). O terceiro tipo é definido da seguinte forma: (3) "um direito é "formal" na medida em que se limita a considerar, no direito material e no processo, as características gerais unívocas dos fatos" (Idem, ibidem). Ou seja, no modelo racionalmente formal vigora uma estrita racionalidade lógica e a univocidade das características externas do direito desaparece. Já no modelo de (4) direito materialmente racional temos que as decisōes de problemas jurídicos sofrem a influência de normas qualitativas, como imperativos éticos, regras de convivência (utilitárias ou de outra natureza) ou máximas políticas que rompem com o formalismo jurídico.

A dicotomia entre o aspecto material e formal do direito é retomada por Weber para visualizar também a evolução histórica do direito, momento em que ele destaca a influência dos fatores externos na racionalização jurídica. Entre estes, três em especial, são considerados: os fatores políticos, religiosos e econômicos. Analisando a racionalização do direito sob uma perspectiva histórica ampla, Weber resumiu assim todo este processo:

As qualidades formais do direito desenvolvem-se nesse processo a partir da combinação de um formalismo magicamente condicionado a uma irracionalidade determinada pela origem em revelações, no procedimento jurídico primitivo, passando, eventualmente, por uma racionalidade material ou não formal, ligada a um fim e patrimonial ou teocraticamente condicionada, rumo a uma racionalidade e sistemática jurídica crescentemente especializada e, portanto, lógica e, por essa via, sob aspectos puramente externos -, ao progresso da sublimação lógica e do rigor dedutivo do direito e da técnica racional do procedimento jurídico" (Idem, p. 143).

\section{Racionalidade teórica e prática}

Se no caso da determinação do significado dos tipos ideais racionalidade formal/racionalidade material tivemos que determinar seu conteúdo a partir do levantamento do seu uso por parte de Weber, o mesmo não ocorre com a outra díade em questão: a racionalidade teórica e prática. Também ela é utilizada por Weber como instrumental heurístico em um contexto bastante determinado e específico de seu corpus textual: seus amplos estudos histórico-comparativos em torno da ética econômica das religiōes 
mundiais (Gesammelte Aufsätze zur Religionssoziologie [Ensaios reunidos de sociologia da religiäo]). Mas, de forma diversa da tipologia anterior, Weber desenha claramente seu significado e escopo analíticos.

Que os conceitos típico-ideais de racionalidade teórica e prática são instrumentos essenciais para sua investigação neste contexto é o próprio Max Weber que no-lo indica quando se refere explicitamente ao seu significado justamente no texto que serve de preâmbulo metodológico aos seus estudos no âmbito da sociologia da religião: a "Einleintug". ${ }^{8}$ Tal documento, além de indicar claramente para o âmbito específico (a esfera religiosa) em que tais conceitos operam como recurso analítico, também indica qual o objetivo da investigação weberiana, ao enfatizar que "também as características das religiōes que têm importância para a ética econômica devem nos interessar aqui essencialmente somente de um ponto de vista determinado: o tipo de sua relação com o racionalismo econômico" (MWG I/19, p. 117; Weber, 2001, p. 259). Em outros termos, a dualidade racionalidade prática e teórica é um dos meios essenciais pelos quais Weber procurou entender "o racionalismo econômico do tipo que começou a dominar o Ocidente nos séculos XVI e XVII como parte da racionalização burguesa que aqui se instala" (Idem, ibidem, grifo meu). Vejamos, pois, o que este texto indica sobre o conteúdo e o significado da tipologia weberiana teórica e prática de racionalidade. No decorrer deste texto, Weber brinda-nos com uma bela súmula a respeito deles, ao afirmar que:

[...] o termo [racionalismo] pode fazer pensar nessa espécie de racionalização que empreende, por exemplo, o pensador sistemático com a imagem do mundo [Weltbild] e que aumenta seu domínio teórico da realidade [theoretische Beherrschung der Realität] mediante a utilização de conceitos abstratos cada vez mais precisos; ou ainda na racionalização no sentido de realização metódica de um fim determinado, dado na prática, mediante um cálculo cada vez mais preciso dos meios adequados. Trata-se de coisas bem distintas, apesar do fato de que em última instância estejam inseparavelmente relacionadas (Idem, ibidem, grifos meus).
O significado da racionalidade teórica [theoretische Rationalität] está correlacionado com os termos visão, imagem [Weltbild] e observação do mundo [Weltbetrachtung]. É em cada um desses diferentes âmbitos que se realiza o domínio conceitual e teórico sobre a realidade, através de conceitos cada vez mais precisos e abstratos, aspectos que definem este tipo de racionalidade, como expressam as próprias palavras de Weber. Nesta medida, ele confere especial importância ao papel da teodiceia (e a ideia de explicação do sofrimento) no processo de racionalização teórica: "Essa religiosidade pressupunha o mito de um salvador, ou seja, uma (ao menos de forma relativa) visão racional do mundo" (Idem, p. 92; Idem, p. 239, grifo no original). A teodiceia do sofrimento representa, portanto, um vetor fundamental no processo de racionalização da imagem de mundo, pois:

Em determinadas circunstâncias, o poder destes fatores singulares experimentou um grande incremento devido à necessidade, de urgência paralela à crescente racionalidade da visão de mundo, de um "sentido" ético para distribuição da fortuna [Glücksgüter] entre os homens. Ao aumentar a racionalidade do ponto de vista ético-religioso e irem se eliminando as primitivas ideias mágicas, a teodiceia do sofrimento encontrou dificuldades crescentes (Idem, p. 94; Idem, p. 241).

Fundamental para a compreensão dos diferentes tipos racionalidade também é a sua relação com fatores sociais, em especial o modo como elas estão relacionadas com a influência de diferentes camadas portadoras [Träger]. Segundo Weber, "os intelectuais e os negociantes (comerciantes, artesãos) foram (os primeiros sempre e os outros, às vezes) sujeitos de um racionalismo, mais teórico no primeiro caso, mais prático no segundo, configurado dos modos mais diversos, mas que teve um grande influxo sobre a atitude religiosa" (Idem, p. 101; Idem, p. 246). Na tipologia weberiana, os dois tipos de racionalidade são construçōes típico-ideais ancoradas na influência de diferentes grupos e camadas sociais na constituição de suas características. Com base nesta premissa, podemos entender por que 
existe afinidade entre racionalidade teórica e camadas intelectuais: "e precisamente esta exigência, a busca do sentido global do cosmos, que é o produto básico do racionalismo propriamente religioso, foi inteiramente conduzida pelas camadas intelectuais" (Idem, p. 102; Idem, p. 247).

Do ponto de vista de sua definição geral, o que caracteriza o conceito de racionalismo prático [praktische Rationalität], para retomar a formulação de Weber, é a "realização metódica de um fim determinado, dado na prática, mediante um cálculo cada vez mais preciso dos meios adequados" (Idem, p. 117; Idem, p. 259, grifo meu). Temos, portanto, dois elementos que o caracterizam: um de caráter dado e prático e outro realizado mediante o cálculo preciso dos meios mais adequados para sua consecução. O que Weber persegue ao recorrer à ideia de racionalismo prático é, segundo suas palavras, uma disposição sistemática para certas condutas. Ou, como ele enfatiza ainda nesta passagem:

Em geral, todos os tipos de ética prática que se orientaram sistematicamente e univocamente para metas fixas de salvação foram 'racionais', em parte no mesmo sentido do método formal, e em parte também no sentido do normativamente 'válido' e do empiricamente dado. Este tipo de processos de racionalização que acabamos de mencionar é o que nos interessará a seguir (Idem, p. 118; Idem, p. 260, grifos meus).

Isto significa que para compreender o processo de racionalização na esfera religiosa Weber deu especial ênfase ao papel dos valores éticos enquanto meio privilegiado pelo qual ocorreu, historicamente, a sistematização do modo de vida. Em outras palavras, Weber opta por mostrar que é o conteúdo moral das religióes que responde pela realização metódica dos fins e pela adoção de cálculos pelos quais os indivíduos moldaram, ao longo da história (e, em particular, no Ocidente), sua conduta de acordo com valores. Note-se que, em sentido geral e abstrato, o conceito de racionalidade prática é determinado pela adequação entre meios e fins; mas, do ponto de vista concreto e histórico-empírico, o que interessa a Weber é descrever o processo de regulação moral da ação social. Ou, nas palavras do próprio autor: "sobre os motivos que determinaram, enquanto tais, os diferentes tipos de 'racionalização' ética da conduta de vida [etischer 'Rationalisierung' der Lebensführung], falaremos frequentemente adiante" (Idem, p. 89; Idem, p. 237, grifo meu).

Como a racionalidade teórica, também a forma prática de racionalidade está ligada ao modo de vida de camadas específicas. Segundo a explicação de Weber, "completamente distinto foi o que ocorreu quando as camadas sociais determinantes do desenvolvimento de uma religião foram os estratos de vida ativa" (Idem, p. 104; Idem, p. 249). Concretamente, "comum a todos estes tipos tem sido a tendência à racionalidade prática do estilo de vida, condicionada pelo maior alheamento da dependência econômica da natureza. Sua existência inteira repousa sobre a dominação e o cálculo técnico ou econômico da natureza e dos homens, por primitivos que sejam seus meios" (Idem, p. 106; Idem, p. 251).

A dicotomia racionalidade teórica/racionalidade prática também permeia este outro importante escrito teórico-reflexivo da sociologia histórico-comparada de Weber: a "Zwischenbetrachtung" ["Consideração intermediária”]. Aliás, é neste texto que, de forma enfática, uma vez mais, o autor nos lembra do objetivo global de seus estudos: "finalmente e, sobretudo, uma busca deste tipo em sociologia da religião deve e quer ser ao mesmo tempo uma contribuição para a tipologia e a sociologia do próprio racionalismo" (Idem, p. 481; Idem, p. 528). Neste contexto, a dicotomia racionalidade teórica e racionalidade prática possui uma função vital: "o racional, no sentido da 'coerência' lógica ou teleológica de uma tomada de posição [Stellungnahme] teórico-intelectual ou ético-prática, exerce e tem exercido sempre poder sobre os homens, por muito limitado e instável que este seja e tenha sido sempre em face dos outros poderes da vida histórica” (Idem, p. 480; Idem, p. 528, grifos meus). Weber diferencia claramente a racionalidade teórica (associada ao aspecto intelectual) e a racionalidade prática (associada ao aspecto ético), temática da qual tratará, extensa e conjuntamente, no trecho seguinte: 
Porém, precisamente as interpretações religiosas do mundo [racionalidade teórica] e as éticas religiosas com pretensão de racionalidade [racionalidade prática] criadas por intelectuais estão intensamente submetidas ao imperativo da coerência. Por muito pouco que, em certos casos, tenham satisfeito a exigência de 'falta de contradição' e ainda que tenham desejado incluir em seus postulados éticos atitudes não dedutíveis racionalmente, pode-se observar claramente em todas elas o efeito da ratio, especialmente da dedução teleológica de postulados práticos (Idem, p. 480; Idem, p. 528, acréscimos meus).

$\mathrm{Na}$ sequência do texto, sabemos que Weber retomará as interpretações religiosas do mundo (racionalidade teórica) e, de modo fundamental, a ética das religiões (racionalidade prática), mostrando de que modo a legalidade própria [Eigengesetzlichkeit] das ordens sociais modernas colide e se torna autônoma diante das exigências de imperativos morais e religiosos. Contudo, esta análise não é o foco deste trabalho: importa sublinhar aqui a presença e importância que a tipologia racionalidade teórica e racionalidade prática adquire no âmbito da sociologia weberiana da religião.

No tópico final do ensaio Confucionismo e taoismo (denominado "Resultados: confucionismo e puritanismo") também encontramos outro esclarecimento da maior importância. Nas palavras de Weber:

Para apreciar o nivel de racionalização que uma religião representa podemos usar dois critérios básicos, que se inter-relacionam de várias maneiras. O primeiro é o grau em que uma religião se despojou da magia; o outro é o grau de coerência sistemática que imprime a relação entre Deus e o mundo e, em consonância com isso, à sua própria relação ética com o mundo (1991, p. 151, grifo meu).

Esta passagem é particularmente vital porque se trata de um dos poucos momentos em que Weber explicita de que forma entende a relação entre estes dois conceitos centrais de sua sociologia: 1) racionalização e 2) desencantamento do mundo [Ent- zauberung der Welt]. Com base nesta orientação sabemos que o conceito típico-ideal de desencantamento do mundo está subordinado ao conceito maior e estruturante de sua sociologia: a racionalização. É a partir deste contexto que o conceito de desencantamento recebe sua determinação como "critério" que aponta para o "nível" de racionalização de determinado contexto religioso. ${ }^{10}$

\section{Algumas consequências teóricas}

Feito o exame exegético-hermenêutico, retorno ao nível teórico e me pergunto sobre as implicações que as análises precedentes nos permitem levantar. Embora entenda que a teoria weberiana da racionalização não possa ser reduzida à mera derivação de conceitos de racionalidade que a informam (entre outros recursos analíticos empregados por Weber), nesta terceira parte conduzirei a discussão em torno da seguinte questão: o que o exercício de situar os conceitos de racionalidade nos escritos de Max Weber pode nos ensinar a respeito do entendimento destas mesmas categorias e, principalmente, sobre a própria ideia de racionalização na sociologia weberiana?

No tocante ao primeiro aspecto - a racionalidade -, da análise anteriormente efetuada resulta assentado que Weber se utilizou dos pares típico-ideais de racionalidade - material/formal e teórica/prática - momentos distintos de sua obra: o primeiro em Economia e sociedade e o segundo em seus Ensaios reunidos de sociologia da religiāo. O levantamento exegético aqui realizado confirma que, longe de reduzir-se a apenas um fator, Weber recorreu a quatro conceitos de racionalidade que estão distribuídos na forma de dois pares típico-ideais. Este dado já nos permite uma importante crítica da bibliografia especializada. Resultam equivocadas as interpretaçôes que ignoram um dos pares em questão e derivam todo o conteúdo do conceito weberiano de racionalidade de apenas uma das díades apresentadas, reduzindo-o apenas ou à sua dimensão material/formal ou à sua dimensão teórico/prática. Acresce ainda que mesmo as interpretaçôes que levam em conta a ocorrência dos quatro conceitos de racionalidade tendem a um tratamen- 
to global e simultâneo dos mesmos, sem levar em conta sua inserção em diferentes loci textuais e, em consequência, sem balizar adequadamente a funcionalidade teórica distinta à qual estes dois pares típico-ideais respondem. O conceito weberiano de racionalidade é um recurso heurístico formulado de modo múltiplo, e sua sistematização típico-ideal obedece a imperativos que resultam de finalidades teóricas que Weber se colocou em função de contextos de análise diferenciados.

Mais amplos e complexos se tornam os problemas quando exploramos os nexos que ligam o âmbito categorial da racionalidade e a explanação weberiana dos processos de racionalização. Seguindo esta trilha, gostaria de chamar a atenção para três aspectos que dizem respeito ao âmbito, à dinâmica e, por fim, ao próprio sentido do tema da racionalização em Weber.

Em primeiro lugar, caberia começar lembrando que os conceitos de racionalidade teórica/prática e material/formal operam em planos distintos das análises weberianas que concernem à racionalização. $\mathrm{O}$ primeiro dos pares em questão é um recurso analítico utilizado por Weber em seus estudos histórico-comparativos (Ensaios reunidos de sociologia da religiāo) e, como tal, ele se circunscreve a um plano social mais limitado, qual seja, o plano da esfera religiosa. O mesmo não acontece com os conceitos de racionalidade material e formal, os quais podem ser explicitamente identificados em suas análises do campo econômico e jurídico, mas também estão implicitamente presentes em suas pesquisas, por exemplo, no campo político e científico (temas desenvolvidos, especialmente, em Economia e sociedade). Em suma, enquanto a díade racionalidade teórica e racionalidade prática possui um âmbito de atuação bem mais específico e determinado, a tipologia racionalidade material e racionalidade formal opera em planos mais vastos, atravessando estruturalmente o conjunto das ordens sociais de vida que aparecem na pesquisa de Weber.

A inserção dos conceitos de racionalidade em planos diferenciados indica não apenas que Weber os utilizou para analisar o processo de racionalização em esferas (histórico-sociais) diferentes, mas também que a própria dinâmica pela qual o processo de racionalização é descrito por Weber nestas respectivas esferas adquire conotações diferentes. Nas suas análises da esfera religiosa (sob o ângulo comparativo), são os conceitos de racionalidade teórica/prática (associados ao não menos importante conceito de desencantamento religioso do mundo) que estruturam a análise; enquanto nas demais esferas (economia, direito e, sob outra ótica, a própria religião) são os conceitos de racionalidade material/formal que articulam a pesquisa. Deste fator resulta que o que vem descrito na esfera religiosa como processo contingente de institucionalização de um racionalismo prático com feiçôes culturais distintas de outros tipos de racionalismo (no Ocidente predomina o racionalismo da dominação do mundo) é pensado, sob outro ângulo, como a transição da racionalidade material para a racionalidade formal, processo que recobre amplas esferas da vida social em tempos modernos. Em suma, a análise weberiana da racionalização não apenas contempla sua ocorrência em planos sociais distintos (que poderiam ser pensados internamente de forma homogênea), mas também apanha lógicas distintas de operação e processos de desenvolvimento próprios e específicos. As descriçôes que Weber nos fornece sobre o modo como se processa a racionalização são diferentes conforme suas balizas se orientam pelos conceitos de racionalidade teórica/prática ou material/formal.

Em síntese, o que podemos dizer até aqui é que a análise weberiana dos processos de racionalização é pluridimensional e explora a variedade de dinâmicas que recortam estas diferentes dimensões. Tal constatação também nos permite dizer que, sem negar sua base comum, o próprio sentido da ideia weberiana de racionalização também é múltiplo, podendo ser desenvolvido e lido em diferentes planos e dimensões. Em Weber, a análise do processo de racionalização é sempre típico-ideal e, neste prisma, pode-se reconhecer que ele adquire tons e perspectivas diferentes (mas não contraditórios e nem excludentes) conforme ele está posto - analiticamente - por Weber em Economia e sociedade ou nos Ensaios de sociologia da religião.

Tal hipótese de leitura repousa sobre um pressuposto anterior: a consideração de que os Ensaios reunidos de sociologia da religião e seu escrito póstumo, Economia e sociedade, constituem escritos 
com finalidades distintas, mas também complementares. Ambos os conjuntos de textos foram concebidos por Weber na fase final de sua vida e, embora não contraditórios, possuíam um escopo diferenciado. Enquanto Economia e sociedade é, essencialmente, um tratado teórico-sistemático de sociologia (que discute a relação entre as ordens e poderes sociais e a vida econômica), os Ensaios de sociologia da religião representam um programa teórico-empírico de pesquisa. No entanto, os textos também se complementam, pois as categorias sociológicas de Economia e sociedade orientam as pesquisas empíricas de Weber e, estas, por sua vez, servem de substrato material para a construção de suas categorias analíticas. Trata-se, a meu ver, de uma chave de leitura possível, em cujo apoio, por ora, posso invocar apenas a pena de um de seus principais comentadores:

Assim, por meios destes dois projetos, Weber perseguiu duas diferentes tarefas no âmbito de uma abordagem unificada das ciências culturais. Isto explica por que eles, em grande parte, se referem aos mesmos objetos de análise e, ao menos no início, utilizam-se da mesma fonte material. Não apenas os objetos de análise são os mesmos, mas também as questôes: qual é a base do caráter único do Ocidente, especialmente do moderno Ocidente? Como ele se desenvolve? E, ainda, qual é a sua tendência de desenvolvimento? (Schluchter, 1989, p. 46).

Estando correto o pressuposto, também seria possível inferir que o sentido da racionalização adquire tonalidades distintas conforme o locus textual em que se insere. É como se Weber nos proporcionasse ângulos diferentes do mesmo fenômeno, mas com preocupaçōes e ênfases diversas. Dessa forma, em Economia e sociedade a análise da racionalização está presente nas múltiplas esferas que recobrem desde o direito e a economia (onde o tema é nomeado de forma explícita), até a ciência, a religião ou mesmo a esfera da política. Nesses campos, a dinâmica de racionalização percorre um caminho que vai do "material" ao "formal", mas isto não deve ser entendido de forma homogeneizante, pois delimitar qual con- teúdo, concretamente, é adquirido em cada uma das esferas pela racionalidade material e pela racionalidade formal é questão que fica em aberto, permitindo-nos apenas captar sua legalidade própria. O resultado final é que Weber apresenta um amplo quadro em que descreve a racionalização pensada em sua dimensão histórico-estrutural. $\mathrm{Ou}$ seja, o que temos aqui é uma análise cujo foco reside na caracterização sistemático-sociológica das ordens sociais racionalizadas do mundo moderno. Já nos Ensaios reunidos de sociologia da religiāo, é fato que Weber parte de uma esfera localizada e determinada (a religião), mas sua análise não se limita nem se fecha apenas neste campo. Ao percorrer a via religiosa, Weber busca contrastar a experiência ocidental de racionalização com outras experiências culturais e obtém como resultado final um amplo quadro comparativo que lhe permite determinar os traços peculiares e contingentes do racionalismo ocidental. Neste caso, é a dimensão histórico-cultural que ganha relevo. Para retomar a terminologia de Habermas, trata-se de uma perspectiva que apanha a racionalização no seu duplo aspecto de processo social (Economia e sociedade) e cultural (Ensaios reunidos de sociologia da religião).

\section{Considerações finais}

Tomar como fio condutor para a compreensão da teoria da racionalização de Max Weber seus conceitos de racionalidade (teórica/prática e material/formal) nem de longe nos permite reconstruir esta teoria em todo seu conteúdo e amplitude. Nem este é o caminho que por si só teria o poder de dissolver todas as dúvidas e os problemas que a interpretação da obra de Weber apresenta. Trata-se, a meu ver, de um ângulo privilegiado, mas este é apenas um aspecto de uma questão que envolve muitas outras determinantes.

Por outro lado, dada a centralidade que o tema possui no pensamento de Max Weber, a compreensão da visão weberiana da racionalização com base nesses conceitos pode nos ensinar muito sobre a estrutura interna desta teoria, quer dizer, a maneira pela qual Weber se serve de diferentes 
aspectos da racionalidade como um (entre outros) dos recursos analíticos que lhe permitem retratar os fatores e as vias que modelam histórica e sociologicamente os processos de racionalização. Prestar atenção no papel que os conceitos de racionalidade exercem como subsídio para modelar a visão weberiana sobre os processos de racionalização nos coloca em contato direto com os esquemas metodológicos desta vertente sociológica. Com base neste pressuposto, procurei demonstrar que o atento exercício exegético de localização dos tipos ideais de racionalidade na obra de Weber fornece indicações importantes para a crítica da bibliografia especializada e, sobretudo, para a compreensão de seu significado. Ademais, também aponta aspectos importantes para a compreensão da temática weberiana da racionalização. Trata-se de um exercício que desvela as diferentes esferas e direções em que Weber descreve o processo de racionalização da ação social, ao mesmo tempo em que aponta para os múltiplos sentidos ou leituras que a tese da racionalização desenvolve.

Conclusivamente, o que se pode dizer, com certeza, é que o tema da racionalidade e da racionalização, em Max Weber, é um exemplo a mais da multiplicidade e, acima de tudo, da riqueza de perspectivas que este pensador utilizava para interpretar, na forma de tipos ideais, a complexidade de um real que está sempre para além de qualquer tentativa de reprodução in totum no plano epistemológico. Uma lição que, ao preservar o frescor e a eterna juventude das ciências sociais, nos deixa com a liberdade e também a tarefa de buscar sempre novos caminhos para a compreensão da multiplicidade da vida que nos cerca.

\section{Notas}

1 No Brasil, existe apenas uma versão traduzida deste texto (com fonte de língua inglesa) que, seguindo o procedimento de Parsons, foi inserida como "introdução" ao escrito A ética protestante e o espírito do capitalismo (Weber, 1996, pp. 1-15). No texto utilizo o original alemão disponível em (Weber, gars i, 1988, pp. 1-16).

2 O mesmo texto foi republicado em Cohn (2003).
3 Sobre o irracional em Weber, ver Segady (1988) e Sica (1992).

4 Um levantamento bibliográfico sistemático sobre o tema da racionalidade em Weber está disponível em Sica (2000).

5 Exemplo significativo nesse sentido é o da intelectual francesa Colliot-Thélène (1995).

6 Dessa forma, a interpretação de Schluchter busca evitar a redução da sociologia comparativa de Weber a um esquema evolucionista, por um lado, ou meramente histórico-descritivo, por outro. Maiores detalhes sobre este ponto podem ser encontrados em Souza (2000).

7 A complexa história da elaboração e composição deste escrito é reconstruída por Pierucci (2009).

8 Em português, este texto encontra-se disponível tendo como fonte a tradução em inglês realizada por Wright e Mills em sua antologia de textos sobre Weber (Ensaios de sociologia) sob o título de "A psicologia social das religiōes mundiais" (Weber, 1982). Neste trabalho utilizo as versões alemã (MWG I/19) e espanhola (Weber, 2001).

9 O texto também está na tradução de Wright e Mills (Weber, 1982), sob o título de "Rejeiçōes religiosas do mundo e suas direções". Para as traduções utilizei o original alemão (MWG I/19; Weber, 1991) e a tradução espanhola da editora Taurus (Weber, 2001).

10 Neste ponto, sigo a interpretação exposta em Schluchter (1999 e 2009). Sobre o desencantamento do mundo, ver, ainda, Lehmann (2009).

\section{BIBLIOGRAFIA}

BENDIX, Reinhard. (1960), Max Weber: an intellectual portrait. Nova York, Doubleday.

BENDIX, Reinhard \& ROTH, Guenter. (1971), Scholarship and partisanship. Berkeley, University of Califórnia Press.

BRUBAKER, Roger. (1984), The limits of rationality. Londres, Allen \& Unwin.

COHN, Gabriel. (1995), "Prefácio: como um hobby ajuda a entender um grande tema", in Max Weber, Os fundamentos racionais e sociológicos da música, São Paulo, Edusp. . (2003), "Apêndice: sobre o significado da racionalização". Crítica e resignação. São Paulo, Martins Fontes, 2003, pp. 227-242. 
COLLIOT-THÉLÈNE, Catherine. (1995), "Rationalisation et dèsenchantement du monde: problèmes d'interprétation des sociologies des religions de Max Weber”. Archives de Sciences Sociales des Religions, 89 (1): 61-81.

EISEN, Arnold. (1978), "The meanings and confusions of Weberian 'rationality". British Journal of Sociology, 29 (1): 57-70.

FREYER, Hans. (1930), Soziologie als Wirklichkeitswissesnchaft. Lepzig-Berlin, G. B. Teubner.

GERTH, Hans \& MILLS, Charles Wright. (1946), From Max Weber: essays in sociology. Nova York, Oxford University Press.

GLASSMAN, Ronald \& MURVAR, Vatro (orgs.). (1984), Max Weber's political sociology: a pessimistic vision of a rationalization word. Londres, Greenwood Press.

HABERMAS, Jürgen. (1987), Teoria da la acción comunicativa: racionalidad de la acción y racionalización social. Madri, Taurus.

HENNIS, Wilhelm. (1996), La problématique de Max Weber. Paris, PUF.

KALBERG, Stephen. (1980), “Max Weber's types of rationality: cornerstones for the analisys of rationalization process in history". The American Journal of Sociology, 85 (5): 1 145-1 179.

. (1990), "The rationalization of action in Max Weber's sociology of religion”. Sociological Theory, 8 (1): 58-84.

. (1994), Max Weber's comparative historical Sociology. Chicago, University Press.

LANDSHUT, Siegfried. (1929), Kritik der Soziologie. München, Duncker \& Humblot.

LASCH, Scott \& WIMSTER, Sam (orgs.). (1987), Max Weber, rationality and modernity. Londres, Routdlege.

LEHMANN, Harmut. (2009), Die Entzauberung der Welt: zechs studien zu themen von Max Weber. Göttingen, Wallstein.

LEVINE, Donald. (1981), "Rationality and freedom: Weber and beyond”. Sociological Inquiry, 51 (1): 5-25.

LÖWITH, Karl. ([1929] 1997), “Max Weber e Karl Marx”, in René Gertz (org.). Max Weber \& Karl Marx, 2. ed., São Paulo, Hucitec.

LUKÁCS, Georg. ([1923] 1974), História e consciência de classe. Porto, Publicações Escorpião.
NELSON, Benjamin. (1974), "Max Webers 'Authors Introduction' (1920): A master clue to his main aims". Sociological Inquiry, 44 (4): 267-278.

PARSONS, Talcott. (1937), The structure of social action. Nova York, MacGraw-Hill.

PIERUCCI, Antonio Flávio. (1998), "Secularização em Max Weber: da contemporânea serventia de voltarmos a acessar aquele velho sentido". Revista Brasileira de Ciências Sociais, 37: 43-73.

. (2003), O desencantamento do mundo: todos os passos do conceito em Max Weber. São Paulo, Editora 34.

SCHLUCHTER, Wolfgang. (1979), "The paradox of rationalization: on the relation of ethics and world", in Guenter Roth e Wolfgang Schluchter (orgs.), Max Weber's vision of history: ethics \& methods, Berkeley, University of California Press, pp. 11-64.

(1981), The rise of Western rationalism: Max Weber's developmental history. Berkeley, University of California Press.

(1989), Rationalism, religion and domination: a Weberian perspective. Berkeley, University of California Press.

- (1996), Paradoxes of modernity: culture and conduct in the theory of Max Weber. Stanford, University Press.

. (1999), "Religion und Rationalismus", in Wolfgang Mommsen e Wolfgang Schwentger (orgs.), Max Weber und das Moderne Japan, Göttingen, Vandenhoeck \& Ruprecht, pp. 121-135.

. (2009), Die Entzauberung der Welt. Tübingen, Mohr Siebeck.

SEGADY, Thomas. (1988), "Rationality and irrationality: new directions in the Weberian theory, critique and research". Sociological Spectrum, pp. 8-85.

SEYFARTH, C. \& SPRONDEL, W. (eds.). (1973), Seminar: Religion und gesellchaftliche Entwicklung. Frankfurt, Suhrkamp.

SICA, Alan. (1992), Weber, irrationality and social order. Berkeley, Berkeley University Press. . (2000), "Rationalization and culture", in Stephen Turner (ed.), The Cambridge Com- 
panion to Weber, Cambridge, Cambridge University Press, pp. 42-58.

SOUZA, Jessé. (2000), "Max Weber e a singularidade da cultura ocidental: cultura normativa ou reificação do mundo?", in . A modernização seletiva: uma reinterpretação do dilema brasileiro, Brasília, Editora da UnB.

STEDING, Christoph. (1932), Politik und Wissenschaft bei Max Weber. Breslau/Teilbruck/ Marburg, Druck von W.G. Korn.

SWEDBERG, Richard. (2005), Max Weber e a ideia de sociologia econômica. Rio de Janeiro, Editora da UFRJ.

SWIDLER, Ann. (1973), "The concept of rationality in the work of Max Weber". Sociological Inquiry, 43 (1): 35-42.

TENBRUCK, Friedrich. (1975), "Das Werk Max Webers”. Kölner Zeitschrift für Soziologie und Sozialpsychologie, 27: 663-702, 1975.

. (1980), "The problem of thematic unity in the works of Max Weber". British Journal of Sociology, 30: 113-199.

TURNER, Bryan. (1992), Max Weber, from history to modernity. Londres, Routledge.

TURNER, Stephen (org.). (2000), Cambridge Companion to Weber. Cambridge, Cambridge University Press.

WALTHER, Andreas. (1926), "Max Weber als Soziologe". Jahrbuch für Soziologie (ed. H. Salomon), 2: 1-65.

WAIZBORT, Leopold. (1995), "Introdução", in Max Weber, Os fundamentos sociológicos e racionais da música, São Paulo, Edusp, pp. 23-52.

WEBER, Marianne. (1926), Max Weber. Ein Lebensbild. Tübingen, Mohr Siebeck.

WEBER, Max. (1982), "A psicologia social das religiōes mundiais (Einleintug)", in

Ensaios de sociologia, 5. ed., Rio de Janeiro, Guanabara, pp. 309-346.

(1982A), "Rejeições religiosas do mundo e suas direçôes (Zwischenbetrachtung)", in Ensaios de sociologia, 5. ed., Rio de Janeiro, Guanabara, pp. 371-410.

(1988), "Vorbemerkung", in . Gesammelte Aufsätze zur Religionssoziologie I [GARS I], Tübingen, Mohr Siebeck, pp. 1-16.
. (1991), "Religiāo e racionalidade econômica”, in Gabriel Cohn (org.), Weber, 5. ed., São Paulo, Ática.

. (1991A), "Einleitung", in

Die Wirtschaftsethik der Weltreligionen: Konfuzianismus und Taoismus (Schriften und Reden 1915-1920). Ed. por Helwig Glintzer e Petra Kolonko. Tübingen, Mohr Siebeck, pp. 209234 (Max Weber Gesamtausgabe - MWG I/19). . (1991B), "Zwischenbetrachtung: Theorie der Stufen und Richtungen religiöser Weltablehnung", in - Die Wirtschaftsethik der Weltreligionen: Konfuzianismus und Taoismus (Schriften und Reden 1915-1920). Ed. por Helwig Glintzer e Petra Kolonko. Tübingen, Mohr Siebeck, pp. 1-26 (Max Weber Gesamtausgabe - MWG I/19).

- (1994), Economia e sociedade: fundamentos da sociologia compreensiva. 3. ed. Brasília, Editora da UnB, vol. 1.

. (1995), Os fundamentos racionais e sociológicos da música. São Paulo, Edusp.

. (1996), "Introdução [Vorbemerkung]", in A ética protestante e o espírito do capitalismo, 11. ed., São Paulo, Pioneira, pp. $1-15$.

. (2001), Ensayos sobre sociología de la religión. Madri, Taurus, vol. 1. . (2004), A ética protestante e "espirito" do capitalismo. Tradução de José Marcos Mariani de Macedo e coordenação técnica de Antônio Flávio Pierucci. São Paulo, Companhia das Letras.

WHIMSTER, Sam \& LASH, Scott (eds.). (1987), Max Weber, rationality and modernity. Londres, Allen \& Unwin, 1987. 


\section{RACIONALIDADE E RACIONALIZAÇÃO EM MAX WEBER}

\section{Carlos Eduardo Sell}

Palavras-chave: Max Weber; Racionalidade; Racionalização; Intelectualismo.

A interpretação da teoria da racionalização social de Max Weber constitui um dos tópicos mais controversos da literatura especializada no pensamento deste autor. Visando enfrentar este complexo tema, este artigo sumariza as conclusōes dos principais comentadores que tratam da questão, bem como descreve os conceitos weberianos de racionalidade material e formal e de racionalidade teórica e prática situando-os nos escritos de Max Weber. Com base neste levantamento exegético, apontamos alguns limites da bibliografia secundária, destacando algumas de suas implicaçóes para a compreensão do sentido que a temática da racionalidade e da racionalização adquire no corpus textual weberiano.

\section{RATIONALITY AND RATIONALIZATION IN MAX WEBER}

\section{Carlos Eduardo Sell}

Keywords: Weber; Rationality; Rationalization; Intellectualism.

The interpretation of Max Weber's theory of social rationalization is one of the most controversial topics in the specialized literature concerning the thought of the author. Aiming to address this complex issue, this article summarizes the conclusions of the main commentators who deal with the issue and describes the Weberian concepts of formal and material rationality, and theoretical and practical rationality, placing them in the writings of Max Weber. Based on this exegetical survey, the article points out to some limits of the secondary literature and highlights some of their implications for understanding the sense that the theme of rationality and rationalization takes in the corpus of Weber's works.

\section{RATIONALITÉ ET RATIONALISATION SELON MAX WEBER}

\section{Carlos Eduardo Sell}

Mots-clés: Weber; Rationalité; Rationalisation; Intellectualisme.

Linterprétation de la théorie de la rationalisation sociale de Max Weber est l'un des thèmes les plus controversés de la littérature chez cet auteur. En vue d'affronter ce thème complexe, cet article résume les principales conclusions des commentateurs qui abordent cette question et décrit les concepts wébériens de rationalité matérielle et formelle et de rationalité théorique et pratique en les plaçant dans les écrits de Max Weber. Basé sur cette enquête exégétique, l'article souligne certaines limites de la littérature secondaire et met en lumière certaines de ses implications pour la compréhension du sens que le thème de la rationalité et de la rationalisation prend dans le corpus wébérien. 